\title{
A Study of the Language Learning Motivation of Saudi Military Cadets
}

\author{
Ali Falah Alqahtani (Corresponding author) \\ Department of Languages, King Abdulaziz Military Academy, Riyadh, Saudi Arabia \\ E-mail: almadhah@gmail.com
}

Received: 17-12-2016

Accepted: 10-03-2017

Advance Access Published: April 2017

Published: 01-07-2017

doi:10.7575/aiac.ijalel.v.6n.4p.163

URL: http://dx.doi.org/10.7575/aiac.ijalel.v.6n.4p.163

\begin{abstract}
Using Dörnyei's (2009) L2 Motivational Self System as the main theoretical framework, this paper reports a study of Saudi military cadets' motivation to learn English. The study aimed to: a) investigate the usefulness of Dörnyei's model for understanding and explaining English language motivation in this global context; b) capture other motivational factors seen to be relevant to the designated group's motivation to learn English. A sample of 194 Saudi military cadets participated in the survey. Correlation and regression analysis of the data support the usefulness of the L2 Motivational Self System in assessing participants' motivation to learn English. Language Learning Attitudes was found to be the best predictor of self-reported learning effort. In addition, Instrumentality Promotion and Instrumentality Prevention proved to be strong predictors of self-reported learning effort. Finally, the study hypothesised that a new construct 'Religious Interest' impacted on participants' motivation to learn English, and regression analysis showed this was also a strong predictor of self-reported learning effort.
\end{abstract}

Keywords: Motivation, L2 Motivational Self System, Language Learning Attitudes, Ideal L2 self; Ought-to L2 self, Religious Interest

\section{Introduction}

The relationship between learning a second/foreign language (L2) and motivation has been the concern of many researchers since Gardner and Lambert (1959) developed a socio-psychological model of L2 motivation relying on 'integrativeness' as its core construct. Contemporary theorists of L2 motivation are now sceptical of the validity of the integrativeness notion in today's globalised world where English is widely accepted as a Lingua Franca and losing its association with Anglophone peoples and cultures. Hence, the L2 learners' desire to learn English is no longer necessarily mainly based on their desire to be identified with Anglophone nations (i.e. integrativeness). Instead, their motivation "might be better explained as an internal process of identification within the person's self-concept, rather than identification with an external reference group" (Dörnyei and Csizér, 2002, p. 453). Based on this premise, Dörnyei $(2005,2009)$ proposed the L2 Motivational Self System, which can be regarded as one of the main developments in L2 motivation research in recent years.

English has been credited with playing a crucial role in globalisation, to the extent that scholars like Pennycook (2003) and Ryan (2006) argue that globalisation would not have been possible without it. Similarly, English is assumed to play "an ever larger role within nations, often serving many domestic purposes to educate, to market and sell goods, to control entry to certain professions, inter alia" (Islam, Lamb, and Chambers, 2013, p. 231-232 ). English is also used to mediate international relations both at the official (e.g. at the United Nations) and unofficial level (e.g. in news media). Thus, it is assumed that an individual's sense of national allegiance (i.e. how someone feels about their own country) and their 'self-positioning' within their own local society will affect their motivation for learning English. This study aimed to explore this issue and other factors that might be relevant to the motivation of a specific group (cadets from the Saudi King Abdulaziz Military Academy, hereafter KAMA) using the L2 Motivational Self System as the main theoretical framework

The L2 Motivational Self System has proved its validity in various EFL contexts including Hungary (Csizér and Kormos, 2009), Japan, China, and Iran (Taguchi, Magid, and Papi, 2009), Chile (Kormos, Kiddle, and Csizér, 2011), Indonesia (Lamb, 2012), Pakistan (Islam et al., 2013), and Saudi Arabia (Alqahtani, 2015). Besides the national interest suggested by Islam et al. (2013) in a similar Islamic environment, this study aims to test another factor (religious interest) that may be of relevance to the learners' motivation to learn English in this under-researched context.

\section{Literature review}

\subsection{The L2 Motivational Self System}

Dörnyei (2005) developed his model based on two influential theories from mainstream psychology: 'possible selves' (Markus and Nurius, 1986) and ‘self-discrepancy' (Higgins, 1987). The L2 Motivational Self System consists of three main constructs: the Ideal L2 Self, the Ought-to L2 Self, and the L2 Learning Experience. The Ideal L2 Self is the 
vision that L2 learners have of the future competent/successful L2 user that they want to be. Therefore, it includes those aspirations and hopes that motivate them to put more effort into attempting to reduce the discrepancy between their actual and ideal selves. The Ought-to L2 Self represents the attributes that L2 learners believe they ought to have in order to meet the expectations and wishes of significant others (e.g. parents) and/or avoid unwanted outcomes (e.g. fail an exam); therefore, the Ought-to L2 Self is more extrinsic (less internalised) in nature. Dörnyei (2009, p. 31) asserts that "figures prove that traditionally conceived 'instrumental motivation' can be divided into two distinct types, promotional and preventional, one relating to the Ideal L2 Self, the other to the Ought-to L2 Self". The third component, the L2 Learning Experience, concerns "situation-specific motives related to the immediate learning environment and experience" (Dörnyei, 2005, p. 106). Issues like the curriculum, the impact of the L2 teacher, the experience of success, and the peer group are examples of the L2 Learning Experience.

The Ideal L2 Self has been found to be the most significant construct of the L2 Motivational Self System for predicting L2 learners' intended learning effort (i.e. the criterion measure). In some cases it explained more than $40 \%$ of the variance in the criterion measure, which is "an exceptionally high figure in motivation studies" (Dörnyei and Ushioda, 2011, p. 87). On the contrary, previous studies such as Kormos et al. (2011) and Lamb (2012) have found that the Ought-to L2 Self has less influence on learners' L2 learning effort. Consequently, Kormos et al. (2011) and Taguchi et al. (2009) have suggested that the Ought-to L2 Self might be expected to play a more central role in Asian and Arab contexts "where family expectations are powerful motives" (Dörnyei, Csizér, and Németh, 2006,p. 93). Like the Ideal L2 Self, the L2 Learning Experience has been found to have a significant impact on learners' L2 learning effort. In some studies the L2 Learning Experience was found to contribute more than the Ideal L2 Self to learners' L2 learning effort (Alqahtani, 2015; Csizér and Kormos, 2009; Islam et al., 2013; Lamb, 2012). It is worth mentioning that the variable 'Language Learning Attitudes' used in this study is categorised as forming part of the L2 Learning Experience.

\subsection{National interest and religious interest as motivational factors}

Largely as a result of their dissatisfaction with the validity of the 'integrativeness' notion, a number of contemporary scholars have attempted to reconceptualise this, based on the idea of a more international and less geographically specific Anglophone community. Yashima (2002) suggested that 'international posture' was a potentially important motivational construct. She defines this as an "interest in foreign or international affairs, willingness to go overseas to stay or work, readiness to interact with intercultural partners and [...] openness or a non-ethnocentric attitude toward different cultures" (Yashima, 2002, p. 57). Therefore, motivated language learners in EFL contexts like Japan have the "tendency to relate themselves to the international community rather than any specific L2 group" (Yashima, 2009, p. 145). A number of studies have asserted that some English L2 learners are seeking affiliation and intercultural contact as they found relationships between intercultural contact and English language motivation (Alqahtani, 2015; Aubrey and Nowlan, 2013; Clément and Kruidenier, 1985; Csizér and Kormos, 2008; Dörnyei et al., 2006).

In addition, L2 learners' "attitudes towards their own country and fellow citizens may also be a significant component of their motivation to learn English" (Islam et al., 2013, p. 233). For example, Lamb (2004, p. 16) found that the motivation of a group of Indonesian students was partly shaped by their pursuit of a 'bicultural identity' i.e. "a vision of an English-speaking globally involved but nationally responsible future self”. Studies by Rivers (2011) and Sullivan and Schatz (2009), carried out with Japanese student, found a significant correlation between positive attitudes towards learning English and 'nationalism', which was defined as "perceptions of national superiority and support for national dominance" (Sullivan and Schatz, 2009, p. 486). A number of studies suggest that for Chinese learners of English, belief in the vital role of this language for promoting their own national culture and identity to the world is likely to be a significant source of their L2 motivation (Lo-Bianco, 2009; Orton, 2009). English language educators in China believe that English is likely to facilitate 'easternisation' by carrying Chinese values and interests out into the world, eventually leading to Chinese replacing English as the global language (Orton, 2009).

Focusing on Pakistani students, Islam et al. (2013, p. 234) developed a new construct that they refer to as 'national interest' which includes "attitudes towards national socio-economic development, national integrity and the projection of a positive group/national image in the international arena". This study revealed that national interest contributed to the learners' English language attitudes. This suggested that the image that Pakistani L2 learners have of themselves as future English users was likely to be associated with "a desire for the socio-economic development, internal harmony, and the international reputation of their country" (Islam et al., 2013, p.240). In Jordan, Al-Haq and Al-Masaeid (2009) has found that Jordanian youths who described themselves as "religiously, rather than materialistically, motivated to learn English" believe that learning English would help them to understand western culture and acquire knowledge and skills necessary for developing Jordan and "spreading the true teaching of Islam" (Al-Haq and Al-Masaeid, 2009, p. 283). Just like their Jordanian counterparts, Saudi students thought that learning English was likely to enhance their national identity and religious commitment as they view it as "a religious and a national duty" (Al-Haq and Smadi, 1996, p. 307).

In Saudi Arabia, Islam shapes all aspects of an individual's life, and the Saudi educational system is intended to inculcate a 'pious conservative Muslim life' (Al-Banyan, 1980; Berkey, 2004; Shaw, 2009); for more details see Alqahtani (2015). Therefore, it was not surprising that a number of studies have found that religion is a significant factor affecting the experiences of Saudi students in terms of learning English and intercultural contact. Kubota, Lin, Rich, and Troudi (2006) found that issues like Islamophobia and political events (e.g. 9/11) added to the academic and cultural difficulties experienced by Saudi students during their sojourn in the UK. AlHazmi (2010) study of Saudi students' intercultural engagement in Australia revealed that a religious issue (gender segregation) had impacted on 
their involvement in intercultural contact with their peers. More recently, Alqahtani (2015) focused on Saudi students during their sojourn in the UK, exploring their recognition of and responses to intercultural opportunities as well as their L2 learning. He found that they avoided involvement in activities with their international peers that included behaviours forbidden on Islamic grounds (e.g. drinking alcohol).

In recent times, factors such as Islamophobia, media coverage of the international war on terrorism and political rhetorical have tended to distort the image of Islam "as a religion of tolerance and compassion" (Islam et al., 2013, p. 240). This is likely to cause racialization and othering of Muslim L2 learners in general and Saudi L2 learners in particular (Kubota et al., 2006). Learning English (the international language) may be viewed by some Saudi L2 learners as a religious duty in order to refute the distorted image of Islam and spread its true teachings to the international community of which they consider themselves to be members and this may affect their motivation to learn English.

\subsection{Research questions}

1)

a. How useful is the L2 Motivational Self System as a means of understanding and explaining the English learning motivation of KAMA cadets?

b. What is the relationship between the three components of the L2 Motivational Self System with each other and the reported learning effort?

2) Which other motivational factors seem to be important in understanding the English learning motivation of this group?

\section{Method}

\subsection{Design of the study}

Two main issues were considered when designing this study, namely, the research paradigm and the research approach. This study adopted a positivist paradigm that is generally prominent in the social sciences and educational research (Dörnyei, 2007). It employs the methodological approaches typically used in the natural sciences and involves objective analysis of phenomena and social realities in the forms of "laws or law-like generalizations" (Cohen, Manion, Morrison, and Morrison, 2007, p. 10). A quantitative approach using a structured questionnaire was followed. Quantitative research is known to be systematic, focused, rigorous, tightly controlled and involves precise measurement. In addition, in terms of findings, it produces reliable and replicable data, which might be generalizable to other contexts (Dörnyei, 2007). Therefore, it is not surprising that the quantitative approach predominates in the field of the L2 motivation research (Ushioda, 2009).

\subsection{Participants}

The population of the study consisted of KAMA cadets. Saudi young men who have successfully completed their high school studies are eligible to join KAMA where they spend three years (elementary, intermediate and final) studying a variety of subjects in two major domains: military and civilian. English forms part of civilian studies and all cadets must study this throughout all six terms of their course at KAMA. After successful completion of their studies, they graduate as lieutenants with a bachelor's degree in military sciences. Volunteers for the study from all three levels were recruited by placing an announcement on bulletin boards across the academy. Some $194(9.75 \%)$ of the 1988 cadets at KAMA participated in the study, most of them being from the first two levels: elementary level 99 participants (51\%), intermediate level 80 participants $(41.2 \%)$, and final level 15 participants $(7.7 \%)$. The age of the participants ranged from 18 to 22 .

\subsection{Instrument}

This study used a five-point Likert scale questionnaire with each response being allocated a score ranging from one to five ( strongly disagree $=1$ and strongly agree $=5$ ). The questionnaire items in this study were adapted from a number of recent studies that investigated learners' L2 motivation in various EFL contexts; for example, Dörnyei et al. (2006) in Hungary; Taguchi et al. (2009) in Japan, China, and Iran; Ryan (2009) in Japan; Islam et al. (2013) in Pakistan; Alqahtani (2015) in Saudi Arabia, and You and Dörnyei (2016) in China.

A number of suitably qualified lecturers at KAMA were asked to assess the wording, comprehensibility and suitability of the questionnaire items. Based on their responses, some items were reworded or eliminated. The questionnaire was then piloted with the help of 43 cadets. Following analysis of the data obtained any necessary changes were made.

The final version of the questionnaire consists of 53 items ranging across 11 scales (see Table 1). After being appropriately briefed, the author's colleagues helped to administer the questionnaire and respondents were assured about anonymity before the questionnaire was distributed. 
Table 1. The questionnaire scales

\begin{tabular}{|c|c|c|c|}
\hline & Name of the scale & Purpose & Example \\
\hline 1. & Parental encouragement & $\begin{array}{l}\text { Measures the extent to which the parents } \\
\text { of participants support and encourage } \\
\text { their offspring's English learning. }\end{array}$ & $\begin{array}{l}\text { My parents encourage me to study } \\
\text { English. }\end{array}$ \\
\hline 2. & Ideal L2 Self & $\begin{array}{l}\text { Investigates the imagined personally- } \\
\text { desired self of respondents as future L2 } \\
\text { users. }\end{array}$ & $\begin{array}{l}\text { Whenever I think of my future career, I } \\
\text { imagine myself being able to use } \\
\text { English. }\end{array}$ \\
\hline 3. & Ought-to L2 Self & $\begin{array}{l}\text { Represents 'the imagined future English } \\
\text { using selves' of participants as } \\
\text { demanded or expected by their } \\
\text { significant others. }\end{array}$ & $\begin{array}{l}\text { I believe that learning English is } \\
\text { necessary to me because people } \\
\text { surrounding me expect me to do so. }\end{array}$ \\
\hline 4. & $\begin{array}{l}\text { Language } \\
\text { Attitudes }\end{array}$ & $\begin{array}{l}\text { Investigates whether respondents enjoy } \\
\text { the experience of English learning. }\end{array}$ & I really enjoy learning English. \\
\hline 5. & Intended learning effort & $\begin{array}{l}\text { Is used as the criterion measure to } \\
\text { determine respondents' perceptions of } \\
\text { the effort they put into their English } \\
\text { learning. }\end{array}$ & I am working hard at learning English. \\
\hline 6. & $\begin{array}{l}\text { Instrumentality } \\
\text { promotion }\end{array}$ & $\begin{array}{l}\text { Associates with participants' specific } \\
\text { practical aspirations and hopes for their } \\
\text { future. }\end{array}$ & $\begin{array}{l}\text { I think knowing English would help me } \\
\text { to become a more educated person. }\end{array}$ \\
\hline 7. & $\begin{array}{l}\text { Instrumentality } \\
\text { prevention }\end{array}$ & $\begin{array}{l}\text { Concerns respondents' duties, } \\
\text { obligations, and fears in the future. }\end{array}$ & $\begin{array}{l}\text { I have to learn English because without } \\
\text { passing the English course I cannot } \\
\text { graduate. }\end{array}$ \\
\hline 8. & Cultural interest & $\begin{array}{l}\text { Measures the extent to which } \\
\text { respondents want to enjoy the cultural } \\
\text { products of English-speaking } \\
\text { communities. }\end{array}$ & $\begin{array}{l}\text { I like the music of English-speaking } \\
\text { countries (e.g. pop music). }\end{array}$ \\
\hline 9. & Travelling & $\begin{array}{l}\text { Measures participants' perceptions of } \\
\text { the benefits of learning English for } \\
\text { travelling abroad. }\end{array}$ & $\begin{array}{l}\text { I study English because with English I } \\
\text { can enjoy travelling abroad. }\end{array}$ \\
\hline 10. & National interest & $\begin{array}{l}\text { Investigates participants' perceptions of } \\
\text { the benefits of learning English for the } \\
\text { progress of Saudi Arabia (their own } \\
\text { country). }\end{array}$ & $\begin{array}{l}\text { I think the knowledge of English } \\
\text { language is necessary for Saudi people } \\
\text { to benefit from the scientific } \\
\text { development in the world. }\end{array}$ \\
\hline 11. & Religious interest & $\begin{array}{l}\text { Measures participants' perceptions of } \\
\text { the benefits of learning English for } \\
\text { representing Islam in a better way to the } \\
\text { international community. }\end{array}$ & $\begin{array}{l}\text { As a Muslim, I think the knowledge of } \\
\text { English would help me to represent } \\
\text { Islam to the international community in } \\
\text { a better way. }\end{array}$ \\
\hline
\end{tabular}

\subsection{Procedure for data analysis}

The data obtained from the questionnaire was entered into Statistical Package for the Social Sciences (IBM SPSS Statistics 20). First, in order to test the reliability of the scales the coefficient of internal consistency of all scales was measured. Second, descriptive statistics (including: mean, standard deviation, skewness and kurtosis) were obtained. This procedure was used to "describe the characteristics of the sample" and "check the variables for any violation of the assumptions underlying the statistical techniques that will be used to address the research questions" (Pallant, 2010, p. 53). Finally, correlation and regression analyses were carried out in order to explore relationships between the scales included in the study.

\section{Findings of the study}

\subsection{Reliability analysis and descriptive statistics}

The reliability analysis showed that all the scales obtained acceptable Cronbach's alpha values i.e. above .60, which meets the standards for social sciences research (Pallant, 2010). Therefore, it can be claimed that the questionnaire scales attained internal consistency (see Table 2). Then the normality of the data was assessed using the values of skewness and kurtosis. Values of ' 0 ' for skewness and kurtosis would imply a perfectly normal distribution which is "rather an uncommon occurrence in the Social Sciences" (Pallant, 2010, p. 57). Not obtaining '0' values does not "necessarily indicate a problem with the scale, but rather reflects the underlying nature of the construct being measured" (Pallant, 2010, p. 64). Therefore, when values do not exceed 2.0 for skewness and 7.0 for kurtosis, data can be regarded to be normal (Pallant, 2010; Tabachnick and Fidell, 2007). As expected from studies in this field, the data was not 
perfectly normally distributed; however, it can be claimed that the distribution of the scores was reasonably normal (see Table 2).

The mean and standard deviation values were obtained in order to investigate the motivational scales that score relatively high/low as well as to check any significant variation within the mean values of the scales. This would offer a comprehensive summary of the results which is likely to help with comparison in further investigation. As Table 2 shows, the mean values for all the motivational scales exceeded the midpoint (2.5 out of 5) ranging from 3.29 to 4.41 . This suggests that the students who participated in this study were highly motivated to learn English. Furthermore, multiple factors are likely to affect their desire to learn this language as three motivational scales have mean values above 4.0 (i.e. very high), namely, religious interest (4.41), national interest (4.27), and intended learning effort (4.08). That implies that these Saudi L2 learners are willing to invest effort in learning English, especially for the sake of representing a positive image of Islam to the international community as well as participating in the progress of their own country (see Table 2).

Table 2. Reliability and comparative analysis of Motivational Scales

\begin{tabular}{|c|c|c|c|c|c|c|}
\hline & Name of the scale & $\begin{array}{l}\text { Cronbach's } \\
\text { alpha value }\end{array}$ & Mean & $\begin{array}{l}\text { Standard } \\
\text { deviation }\end{array}$ & $\begin{array}{c}\text { Skewness } \\
\text { value }\end{array}$ & $\begin{array}{c}\text { Kurtosis } \\
\text { value }\end{array}$ \\
\hline 1. & Parental Encouragement & .79 & 3.93 & .69 & -.47 & -.12 \\
\hline 2. & Ideal L2 Self & .84 & 3.92 & .71 & -.61 & -.05 \\
\hline 3. & Ought-to L2 Self & .75 & 3.39 & .77 & -.03 & -.27 \\
\hline 4. & Language Learning Attitudes & .81 & 3.50 & .85 & -.36 & .11 \\
\hline 5. & Intended Learning Effort & .70 & 4.08 & .59 & -.85 & 1.03 \\
\hline 6. & Instrumentality Promotion & .78 & 3.86 & .76 & -.68 & .51 \\
\hline 7. & Instrumentality Prevention & .65 & 3.90 & .72 & -.76 & .46 \\
\hline 8. & Cultural Interest & .71 & 3.29 & .93 & -.22 & -.50 \\
\hline 9. & Travelling & .66 & 3.90 & .88 & -.98 & .92 \\
\hline 10. & National Interest & .66 & 4.27 & .67 & -.91 & .61 \\
\hline 11. & Religious Interest & .71 & 4.41 & .68 & -1.42 & 2.32 \\
\hline
\end{tabular}

\subsection{Correlation analysis}

In order to investigate the strength of the linear relationships that might exist between the motivational scales, a correlation analysis was administered. The strength of the correlations was determined as suggested by Cohen (1988). $\mathrm{He}$ asserts that when the value of the correlation coefficient exceeds .50, the strength of the correlation can be regarded strong. The correlation analysis revealed a number of strong correlations.

The criterion measure (Intended Learning Effort) had a strong linear correlation with three constructs, which were Language Learning Attitudes (.662), Instrumentality-Promotion (.632), and Ideal L2 Self (.554). This suggests that the immediate learning context is likely to have a significant impact on the learners' motivation to learn English. In addition, the correlation between Language Learning Attitudes and Ideal L2 Self was strong (.604), which might indicate that possessing positive attitudes towards learning English is likely to help the learner to create an image of himself as a future L2 user. The Ought-to L2 Self was highly correlated with Instrumentality-Prevention (.643); similarly the correlation between the Ideal L2 Self and Instrumentality-Promotion was quite high (.682). These results confirmed the assertion of previous studies that Instrumentality-Prevention is related to the Ought-To L2 Self while the Instrumentality-Promotion is related to the Ideal L2 Self (Dörnyei, 2009; Islam et al., 2013; You and Dörnyei, 2016). The newly developed construct 'Religious Interest' had a strong linear correlation with 'National Interest' (.552) (see Table 3 for correlation coefficient values).

Table 3. Correlation coefficient values for the scales

\begin{tabular}{|c|c|c|c|c|c|c|c|c|c|c|c|c|}
\hline & Scales & 1 & 2 & 3 & 4 & 5 & 6 & 7 & 8 & 9 & 10 & 11 \\
\hline 1. & Parental Encouragement & & & & & & & & & & & \\
\hline 2. & Ideal L2 Self & .396 & & & & & & & & & & \\
\hline 3. & Ought-to L2 Self & .450 &.$\overline{420}$ & & & & & & & & & \\
\hline 4. & Language Learning Attitudes & .327 & .604 &.$\overline{373}$ & & & & & & & & \\
\hline 5. & Intended Learning Effort & .360 & .554 & .401 &.$\overline{662}$ & & & & & & & \\
\hline 6. & Instrumentality Promotion & .406 & .682 & .535 & .581 & .632 & & & & & & \\
\hline 7. & Instrumentality Prevention & .342 & .328 & .643 & .262 & .407 &.$\overline{442}$ & & & & & \\
\hline & Cultural Interest & .266 & .481 & .370 & .500 & .427 & .420 & .223 & & & & \\
\hline & Travelling & .347 & .468 & .476 & .397 & .465 & .568 & .373 &.$\overline{447}$ & & & \\
\hline & National Interest & .347 & .463 & .454 & .425 & .467 & .531 & .393 & .380 & .442 & & \\
\hline & Religious Interest & .288 & .388 & .402 & .290 & .418 & .431 & .334 & .286 & .324 &.$\overline{552}$ & \\
\hline
\end{tabular}


In order to determine which motivational scales made the greatest contribution to the L2 motivation of the respondents by predicting the reported learning effort (i.e. the criterion measure), a stepwise multiple regression was applied. Firstly, the assumptions of multicollinearity and normality were tested and data showed that these were not violated. Multicollinearity exists "when the values of bivariate correlation among the variables of 0.7 or more" (Pallant, 2010, p. 151). The data also showed that there was no major deviation in normality values and no outliers needed to be excluded. The model of the best predictors for the reported learning effort explains $56 \%$ of the variance in the participants' intended learning effort which can be regarded as a highly respectable value in L2 motivation research (Dörnyei, 2009) (see Table 4).

Table 4. Regression model based on Intended Learning Efforts as the criterion measure

\begin{tabular}{lccc}
\hline \multirow{2}{*}{ Variable } & \multicolumn{3}{c}{ Final model } \\
\cline { 2 - 4 } & $\mathrm{B}$ & SEB & Beta \\
\hline Language Learning Attitudes & .30 & .04 & $.43^{*}$ \\
Instrumentality Promotion & .20 & .05 & $.26^{*}$ \\
Religious interest & .11 & .04 & $.13^{*}$ \\
Instrumentality-Prevention & .10 & .04 & $.13^{*}$ \\
$\mathrm{R}^{2}$ & & .56 & \\
$\mathrm{~F}$ for change in $\mathrm{R}^{2}$ & & $5.71^{*}$ & \\
\hline$* \mathrm{p}<.05$ & & &
\end{tabular}

Table 5. Regression models based on the components of L2 Motivational Self System.

\begin{tabular}{|c|c|c|c|}
\hline \multirow{2}{*}{ Variable } & \multicolumn{3}{|c|}{ Final model } \\
\hline & B & SEB & Beta \\
\hline \multicolumn{4}{|c|}{ Criterion Measure 1: Ideal L2 Self } \\
\hline Instrumentality Promotion & .44 & .05 & $.46^{*}$ \\
\hline Language Learning Attitudes & .21 & .05 & $.25^{*}$ \\
\hline Cultural Interest & .12 & .04 & $.15^{*}$ \\
\hline $\mathrm{R}^{2}$ & & .54 & \\
\hline $\mathrm{F}$ for change in $\mathrm{R}^{2}$ & & $7.50 *$ & \\
\hline \multicolumn{4}{|c|}{ Criterion Measure 2: Ought-to L2 Self } \\
\hline Instrumentality Prevention & .49 & .06 & $.46^{*}$ \\
\hline Instrumentality Promotion & .20 & .06 & $.20^{*}$ \\
\hline Parental Encouragement & .19 & .06 & $.17^{*}$ \\
\hline Cultural Interest & .11 & .04 & $.13^{*}$ \\
\hline $\mathrm{R}^{2}$ & & .53 & \\
\hline $\mathrm{F}$ for change in $\mathrm{R}^{2}$ & & $5.98 *$ & \\
\hline \multicolumn{4}{|c|}{ Criterion Measure 3: Language Learning Attitudes } \\
\hline Intended Learning Effort & .61 & .08 & $.43^{*}$ \\
\hline Ideal L2 Self & .33 & .07 & $.27^{*}$ \\
\hline Cultural Interest & .16 & .05 & $.18^{*}$ \\
\hline $\mathrm{R}^{2}$ & & .53 & \\
\hline $\mathrm{F}$ for change in $\mathrm{R}^{2}$ & & $10.23 *$ & \\
\hline
\end{tabular}

$$
* \mathrm{p}<.05
$$

The model showed that four scales made a significant contribution to predicting the participants' reported learning effort. The strongest of these predictors was Language Learning Attitudes followed by Instrumentality-Promotion, Religious Interest, and Instrumentality-Prevention, respectively. The new construct 'Religious Interest' explains $13 \%$ of the variance in the reported learning efforts. 
In an attempt to ascertain the factors that contributed towards the three components of the L2 Motivational Self System, stepwise multiple regression analysis was conducted based on Ideal L2 Self and Ought-to L2 Self, with Language Learning Attitudes as the criterion measure. The regression models indicated that the strongest predictor of the Ideal L2 Self was Instrumentality-Promotion while Instrumentality-Prevention was the strongest predictor of the Ought-to L2 Self. The models also indicated that Cultural Interest explains some significant variance in all three components of the L2 Motivational Self System (see Table 5).

Finally, a stepwise multiple regression analysis was conducted using 'Religious Interest' as the criterion measure to assess the factors that contributed towards this new construct. Three factors made a significant contribution to the prediction of participants' perceptions of the benefits of learning English for religious purposes. National Interest was the strongest predictor, followed by Intended Learning Effort and Ought-to L2 Self (see Table 6).

Table 6. Regression model based on Religious Interest as the criterion measure.

\begin{tabular}{lccc}
\hline \multirow{2}{*}{ Variable } & \multicolumn{3}{c}{ Final model } \\
\cline { 2 - 4 } & $\mathrm{B}$ & $\mathrm{SEB}$ & Beta \\
\hline National Interest & .40 & .07 & $.40^{*}$ \\
Intended Learning Effort & .19 & .07 & $.16^{*}$ \\
Ought-to L2 Self & .13 & .05 & $.15^{*}$ \\
$\mathrm{R}^{2}$ & & .35 & \\
$\mathrm{~F}$ for change in $\mathrm{R}^{2}$ & & $5.02 *$ & \\
\hline$* \mathrm{p}<.05$ & & &
\end{tabular}

\section{Discussion}

The correlation analysis and regression analysis revealed some relationships among the three constructs of the L2 Motivational Self System; however, this was not sufficient to raise doubts of multicollinearity i.e. measuring the same thing. On the contrary, it supported the view of Dörnyei (2009) and Dörnyei and Ushioda (2011) that the three constructs are distinct and independent as they measure different aspects of L2 motivation. In addition, the regression analysis suggested that Language Learning Attitudes was the best predictor of reported learning effort, which was similar to the findings of a number of recent studies in various L2 contexts; for example, Alqahtani (2015), Islam et al. (2013), Kormos et al. (2011), Lamb (2012), Papi (2010), and Taguchi et al. (2009).

The correlation analysis revealed a strong linear relationship between reported learning effort and Language Learning Attitudes as well as the Ideal L2 Self. In addition, it revealed a strong linear relationship between Language Learning Attitudes and the Ideal L2 Self. This might have indicated the positive attitudes of participants towards the learning process based on their awareness of the importance of English for their future. This, in turn, might have helped them to create an image of themselves as future L2 users (i.e. vision), which was likely to have encouraged them to invest energy and time in their language learning. This was in line with findings reported by Dörnyei and Chan (2013), and You and Dörnyei (2016) who concluded that "vision of one's idealised persona is a valid and potent motivator" for L2 learners (You and Dörnyei, 2016, p. 513).

The correlation coefficients showed a strong linear relationship between Ideal L2 Self and Instrumentality-Promotion; similarly they revealed a strong relationship between Ought-to L2 Self and Instrumentality-Prevention. Moreover, according to the results of regression analysis, Instrumentality-Promotion was the best predictor of Ideal L2 Self while Instrumentality-Prevention was the best predictor of Ought-to L2 Self. This was in line with the findings of a number of recent studies including Islam et al. (2013) and You and Dörnyei (2016) that confirm Dörnyei’s (2009) assertion preposition that instrumental motivation has two distinct aspects (promotional and preventional) that are related to Ideal L2 Self and Ought-to L2 Self, respectively.

Both types of instrumental motivation (Promotion and Prevention) contributed to the reported learning effort. This suggests a positive indication of harmony between the Ideal L2 Self and Ought-to L2 Self, which "is an important condition for maximizing their motivational impact and to induce people to make desired efforts to achieve their goals" (Dörnyei, 2009, p. 18). This coincided with the views held by scholars such as Oyserman, Bybee, and Terry (2006) and Hoyle and Sherrill (2006) that "the most effective condition for future self-guides is a balanced combination of pairs of countervailing selves"; this would suggest "a balanced combination of the ideal and the ought selves" (Dörnyei, 2009, p. 22).

One motivational factor in particular has contributed to all the three components of the L2 Motivational System, which is 'Cultural Interest'. Cultural Interest can be considered "to be part of attitudes to the L2 community" (Taguchi et al., 2009, p. 82). In addition, Ryan (2009) defines Cultural Interest as “concerning the learner's relationships - often imagined - with the speakers of the L2" and argues it can be considered "a form of indirect contact with speakers of the L2" (Ryan, 2009, p. 130). It is worth mentioning that all cadets have the possibility to apply for scholarships to study abroad. Therefore, this might have encouraged them to have an interest in cultural artefacts using the medium of English based on their awareness of the crucial role of English in communicating with the wider international 
community in today's rapidly globalising world (i.e. intercultural contact). This was likely to have encouraged them to have positive attitudes towards the L2 learning process and gave them a purpose and meaning for learning English as they might have started to see themselves as future L2 users. This lends more support to the findings of a number of previous studies that suggest there is a relationship between intercultural contact and English language motivation, for example, Alqahtani (2015), Aubrey and Nowlan (2013), Csizér and Kormos (2008), and Dörnyei et al. (2006).

The new construct developed for this study 'Religious Interest' had a strong linear relationship with 'National Interest'. Furthermore, National Interest as well as Intended Learning Effort and Ought-to L2 Self contributed respectively to 'Religious Interest'. This could be explained from a contextual perspective by underlining the collective nature of Saudi society that encourages "social solidarity among members of the Muslim community through cooperation, love, fraternity and placing the public good over private interests" (Saudi Arabian Cultural Mission in the United States, 1991). Parents raise their offspring on this principle which the Saudi educational system also reinforces. Parental pressure and the state educational system enhance the Saudi L2 learners' sense of responsibility towards their country and the Muslim community in general. Since media coverage of the international war on terrorism and political rhetorical has does much to promote negative images of Islam, the Saudi L2 learners are likely to see learning English "as a positive step towards restoring the health and reputation" of their religion as one of tolerance and compassion (Islam et al., 2013). The sense of duty that Saudi L2 learners feel towards their religion has been reported in studies by Al-Haq and Smadi (1996) and Alqahtani (2015).

Cultural psychology research has found that relational motives for action are likely to be as influential as personal motives for certain individuals. In western cultures it is assumed that "personal motives are the most effective in directing behaviour because they are also expressive of the individual, independent self"; whereas members of eastern cultures "may perceive relational motives as more effective reasons for pursuing goals because they involve a collective interest in the outcome" (Gore, Cross, and Kanagawa, 2009, p. 77). Lamb (2013) noticed that social motives like serving the local community or advancing the interests of the country had infused the Ideal Selves of Indonesian L2 learners. Similarly, Islam et al. (2013) found that National Interest contributed to the L2 motivation of Pakistani L2 learners. Therefore, Religious Interest might be viewed as a relational motive encouraging Saudi L2 learners to invest time and effort in learning English for the sake of their religion.

\section{Conclusion}

This study has again proved the usefulness of the L2 Motivational Self System by employing this to assess L2 learners' motivation to learn English in a specific national and institutional context and then make comparisons with L2 learners in other global contexts. It might be claimed that the motivation to learn English of the designated sample of Saudi military cadets shares some common motivational factors with L2 learners in other EFL context. Besides the components of the L2 Motivational Self System (the Ideal L2 Self, the Ought-to L2 Self, and the Language Learning Attitudes), the proposed construct 'Religious Interest' was revealed to be relevant to the English language motivation of this particular group.

The contribution of Religious Interest to the Saudi cadets' motivation to learn English is noteworthy. Although the L2 motivation of this group in many ways resembles that of L2 learners in other global contexts there is some evidence that specific social and cultural factors may also play a motivational role for these L2 learners. This emphasises the need for L2 motivation researchers to pay close attention to the socio-cultural specificities of the context under investigation.

Finally, this study of Saudi military cadets focused exclusively on young males since KAMA does not admit females. This restricts the generalizability of the findings of this study to the wider community of Saudi L2 learners. Therefore, if the study had been conducted in a different learning environment such as a university, and had included a representative mix of male and female participants, a different motivational profile might have been observed

\section{References}

Al-Banyan, A. S. (1980). Saudi Students in the United States: a Study of Cross Cultural Education and Attitude Change. London: Ithaca Press.

Al-Haq, F., \& Al-Masaeid, A. L. (2009). Islam and Language Planning in the Arab World: A Case Study in Jordan. Iranian Journal of Language Studies, 3(3), 267-302.

Al-Haq, F., \& Smadi, O. (1996). Spread of English and Westernization in Saudi Arabia. World Englishes, 15(3), 307317.

AlHazmi, A. (2010). Saudi International Students in Australia and Intercultural Engagement: A Study of Transitioning From a Gender Segregated Culture to a Mixed Gender Environment (S. o. Education, Trans.) (pp. 1-11). Melbourne: RMIT University

Alqahtani, A. (2015). A Study of Intercultural Contact \& L2 Motivation for Saudi Sojourners. Saarbrucken: Scholars' Press.

Aubrey, S., \& Nowlan, A. G. P. (2013). Effect of Intercultural Contact on L2 Motivation: A comparative Study. In M. T. Apple, D. D. Silva, \& T. Fellner (Eds.), Language Learning Motivation in Japan (pp. 129-151). Bristol: Multilingual Matters. 
Berkey, J. (2004). Education. In M. R.C. (Ed.), Encyclopedia of Islam and the Muslim World (Vol. 1, pp. 202-206). New York: Macmillan.

Clément, R., \& Kruidenier, B. G. (1985). Aptitude, Attitude and Motivation in Second Language Proficiency: A Test of Clement's Model. Journal of Language and social Psychology, 4(1), 21-37.

Cohen, J. (1988). Statistical Power Analysis for the Behavioral Sciences (2nd ed.). Hillsdale, NJ: Lawrence Erlbaum Associates.

Cohen, L., Manion, L., Morrison, K., \& Morrison, K. R. B. (2007). Research methods in education. London ; New York: Routledge.

Csizér, K., \& Kormos, J. (2008). The Relationship of Intercultural Contact and Language Learning Motivation among Hungarian Students of English and German. Journal of Multilingual and Multicultural Development, 29(1), 30-48.

Csizér, K., \& Kormos, J. (2009). Learning Experiences, Selves and Motivatied Learning Bhaviour: A Comparative Analysis of Structural Models for Hungarian Secondary and University Learners of English. In Z. Dörnyei \& E. Ushioda (Eds.), Motivation, language identity and the L2 self (pp. 98-119). Bristol: Multilingual Matters.

Dörnyei, Z. (2005). Psychology of the Language Learner: Individual Differences in Second Language Acquisition. Mahwah, N.J. ; London Lawrence Erlbaum Associates.

Dörnyei, Z. (2007). Research Methods in Applied Linguistics: Quantitative, Qualitative and Mixed Methodologies. Oxford: Oxford Univresity Press.

Dörnyei, Z. (2009). The L2 motivational self system. In Z. Dörnyei \& E. Ushioda (Eds.), Motivation, language identity and the L2 self (pp. 9-42). Bristol: Multilingual Matters.

Dörnyei, Z., \& Chan, L. (2013). Motivation and Vision: An Analysis of Future L2 Self Images, Sensory Styles, and Imagery Capacity across Two Target Languages. Language Learning, 63(3), 437-462.

Dörnyei, Z., \& Csizér, K. (2002). Some Dynamics of Language Attitudes and Motivation: Results of a Longitudinal Nationwide Survey. Applied Linguistics, 23(4), 421-462.

Dörnyei, Z., Csizér, K., \& Németh, N. (2006). Motivation, Language Attitudes and Globalisation: A Hungarian Perspective (Vol. 18). Bristol: Multilingual Matters.

Dörnyei, Z., \& Ushioda, E. (2011). Teaching and Researching Motivation. Harlow: Longman.

Gardner, R. C., \& Lambert, W. E. (1959). Motivational variables in second-language acquisition. Canadian Journal of Psychology/Revue canadienne de psychologie, 13(4), 266-272.

Gore, J., Cross, S., \& Kanagawa, C. (2009). Acting in Our Interests: Relational Self-Construal and Goal Motivation across Cultures. Motivation and Emotion, 33(1), 75-87.

Higgins, E. T. (1987). Self-Discrepancy: A Theory Relating Self and Affect. Psychological Review, 94(3), $319-340$.

Hoyle, R. H., \& Sherrill, M. R. (2006). Future Orientation in the Self-System: Possible Selves, Self-Regulation, and Behavior. Journal of Personality, 74(6), 1673-1696.

Islam, M., Lamb, M., \& Chambers, G. (2013). The L2 Motivational Self System and National Interest: A Pakistani perspective. System, 41(2), 231-244.

Kormos, J., Kiddle, T., \& Csizér, K. (2011). Systems of Goals, Attitudes, and Self-Related Beliefs in Second-LanguageLearning Motivation. Applied Linguistics, 32(5), 495-516.

Kubota, R., Lin, A., Rich, S., \& Troudi, S. (2006). Hard times: Arab TESOL students' experiences of racialization and othering in the United Kingdom. TESOL QUARTERLY, 40(3), 615-627.

Lamb, M. (2004). Integrative Motivation in a Globalizing World. System, 32, 3-19.

Lamb, M. (2012). A Self System Perspective on Young Adolescents' Motivation to Learn English in Urban and Rural Settings. Language Learning, 62(4), 997-1023.

Lamb, M. (2013). 'Your Mum and Dad Can't Teach You!' Constraints on Agency among Rural Learners of English in the Developing World. Journal of Multilingual and Multicultural Development, 34(1), 14-29.

Lo-Bianco, J. (2009). English at Home in China: How Far Does the Bond Extend? In J. Lo-Bianco (Ed.), China and English: globalisation and the dilemmas of identity (Vol. 6, pp. 192-210). Bristol: Multilingual Matters.

Markus, H., \& Nurius, P. (1986). Possible Selves. American Psychologist, 41(9), 954-969.

Orton, J. (2009). East goes west. In J. Lo-Bianco (Ed.), China and English: Globalization and the dilemmas of identity (pp. 271-293). Bristol: Multilingual Matters.

Oyserman, D., Bybee, D., \& Terry, K. (2006). Possible Selves and Academic Outcomes: How and When Possible Pelves Impel Action. Journal of personality and social psychology, 91(1), 188-204.

Pallant, J. (2010). SPSS Survival Manual: A Step by Step Guide to Data Analysis Using SPSS. Milton Keynes: Open University Press.

Papi, M. (2010). The L2 Motivational Self System, L2 Anxiety, and Motivated Behavior: a Structural Equation Modeling Approach. System, 38(3), 467-479. 
Pennycook, A. (2003). Global Englishes, Rip Slyme, and Performativity. Journal of sociolinguistics, 7(4), $513-533$.

Rivers, D. J. (2011). Japanese national identification and English language learning processes. International journal of intercultural relations, 35(1), 111-123.

Ryan, S. (2006). Language Learning Motivation within the Context of Globalisation: An L2 Self within an Imagined Global Community. Critical Inquiry in Language Studies: An International Journal, 3(1), 23-45.

Ryan, S. (2009). Self and Identity in L2 Motivation in Japan: The Ideal L2 Self and Japanese Learners of English. In Z. Dörnyei \& E. Ushioda (Eds.), Motivation, language identity and the L2 self (pp. 120-143). Bristol: Multilingual Matters.

Saudi Arabian Cultural Mission in the United States. (1991). Education in Saudi Arabia. Washington, D.C.: Royal Embassy of Saudi Arabia.

Shaw, D. L. (2009). Bridging differences: Saudi Arabian students reflect on their educational experiences and share success strategies. (Unpuplished PhD), Oregon State University.

Sullivan, N., \& Schatz, R. T. (2009). Effects of Japanese National Identification on Attitudes Toward Learning English and Self-Assessed English Proficiency. International journal of intercultural relations, 33(6), 486-497.

Tabachnick, B. G., \& Fidell, L. S. (2007). Using Multivariate Statistics (5th ed.). Boston: Pearson Education.

Taguchi, T., Magid, M., \& Papi, M. (2009). The L2 Motivational Self System among Japanese, Chinese and Iranian Learners of English: A Comparative Study. In Z. Dörnyei \& E. Ushioda (Eds.), Motivation, language identity and the L2 self (pp. 66-97). Bristol: Multilingual Matters.

Ushioda, E. (2009). A Person-in-Context Relational View of Emergent Motivation, Self and Identity. In Z. Dörnyei \& E. Ushioda (Eds.), Motivation, language identity and the L2 self (pp. 215-228). Bristol: Multilingual Matters.

Yashima, T. (2002). Willingness to Communicate in a Second Language: The Japanese EFL context. The Modern Language Journal, 86(1), 54-66.

Yashima, T. (2009). International Posture and the Ideal L2 Self in the Japanese EFL Context. In Z. Dörnyei \& E. Ushioda (Eds.), Motivation, language identity and the L2 self (pp. 144-163). Bristol: Multilingual Matters Ltd.

You, C. J., \& Dörnyei, Z. (2016). Language Learning Motivation in China: Results of a Large-Scale Stratified Survey. Applied Linguistics, 37(4), 495-519. 